\title{
MEDICAL WASTE MANAGEMENT AT SAMUEL J. MOEDA NAVAL HOSPITAL KUPANG, NUSA TENGGARA TIMUR
}

\author{
Yanik Tri Lestari, Hari Rarindo, and Marthen R. Pellokila \\ School of Health Sciences, Nusa Cendana University
}

\begin{abstract}
Background: Hospital is a public health service agency that produces daily medical waste, especially solid waste that must be handled properly. Although the Indonesian Naval Hospital Samuel J. Moeda has implemented waste management and disposal, management is still ineffective in light of the lack of managerial resources, basic management processes, and incinerator unavailability as a final waste management tool. This study aimed to analyze the management of medical waste starting from input, process, and output, at Samuel J. Moeda Naval Hospital, Kupang, Nusa Tenggara Timur.

Subjects and Method: This study was descriptive with qualitative approach. It was conducted at Samuel J. Moeda Naval Hospital, Kupang, Nusa Tenggara Timur. A sample of 14 informants were selected for this study. The data were collected by in-depth interview, direct obesrvation, and document review. Checklist sheets were used to assist direct observation.

Results: Waste management was not well-performed with limited facilities and infrastructure, unspecified and inadequate budgeting. The process of solid medical waste management was not optimally performed, and there were some errors found during the process. Similarly, the output of solid medical waste management did not meet the standards set by the Minister of Health Regulation No. 1204/ 2004. It appears that waste management issues received little attention from the hospital management.

Conclusion: Medical waste management at Samuel J. Moeda, Naval Hospital, Kupang has not been well-performed. The hospital can pay attention to the potential of medical waste recycle for extended hospital purposes. Recruitment, education, and training, of medical waste management staff are urgently needed. Routine waste management evaluation is also needed to help create a healthy hospital environment.
\end{abstract}

Keywords: solid medical waste, management, hospital

Correspondence: Yanik Tri Lestari. School of Health Sciences, Nusa Cendana University, Kupang, Nusa Tenggara Timur. 